
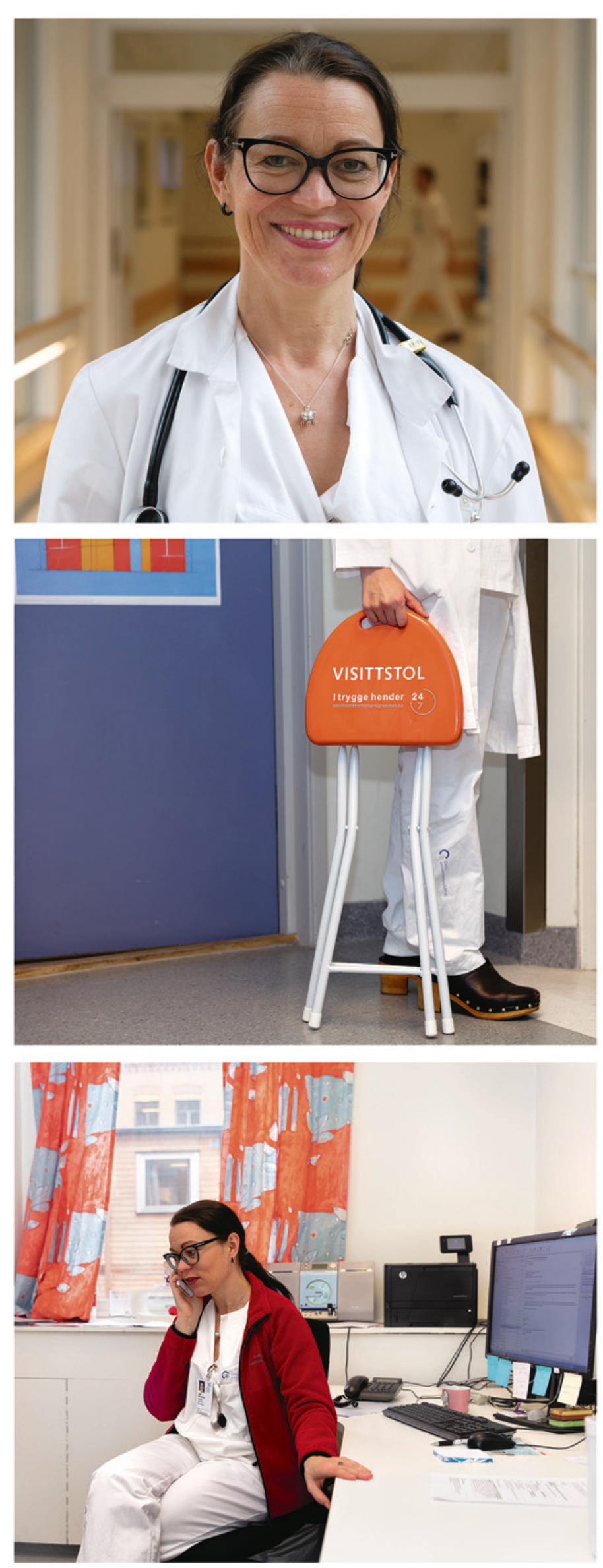

Foto: Christian Tunge

\section{Hjerneslag er blålysmedisin}

Hege Ihle-Hansen er spesialist $\mathrm{i}$ indremedisin og geriatri og jobber ved slagenheten, Oslo universitetssykehus, Ullevål. Ihle-Hansen har doktorgrad i hvordan evnen til å tenke påvirkes av hjerneslag. Hun er postdoktor ved Bærum sykehus innen sammenhengen mellom cerebrovaskulær sykdom og kognisjon og så skriver hun med blyant.

\section{Skjer det noe interessant innen ditt fagfelt?}

Faget hjerneslag er i rivende utvikling. Hjerneslag er blitt blålysmedisin der effektive muligheter til akutt trombolyse og endovaskulær behandling stiller store krav til tidlig og rask diagnostikk. Samtidig bevares hjernen gjennom optimalisering av homeostase og stabilisering av andre kompliserende sykdommer i akuttfasen, parallelt med utredning av årsaken til slaget for forebyggende behandling, samt rehabilitering for å gjenvinne funksjon. Vi slagleger må ha kunnskap om hjernens anatomi og blodsirkulasjon, om aldring med reserver og sårbarhetsfaktorer, om multisykelighet og polyfarmasi, og om mekanismene ved aterosklerose og hjertesykdom. Samtidig møter vi mennesker med akutt hjernesykdom som påvirker deres evne til å tenke - noe som oppleves svært brutalt. En god slaglege må derfor ha evnen til å se helheten, både faglig og menneskelig, arbeide i tverrfaglige team og sjonglere alt på en gang!

\section{Vil du anbefale en ny og spennende artikkel?}

Tidsskriftet JAMA publiserte i mars et intervju med to hjerneforskere som forteller at cerebrovaskulær sykdom antakelig medvirker i årsaksrekken til Alzheimers sykdom gjennom påvirkning av blod-hjernebarrieren og amyloidavleiring (1). Dette åpner for ny forståelse av degenerative hjernesykdommer. Videre bekrefter det at god karforebyggende behandling er viktig for å bevare hjernehelse.

\section{Hva er ditt favoritthjelpemiddel på jobb?}

Visittstolen! Når vi snakker med våre pasienter, må vi sitte, bruke tid på anamnesen og lytte til pasientens symptomer og opplevelser, undringer og usikkerhet. Vi må forklare hva som har skjedd, og gi kunnskap om sykdommen for mestring, etterlevelse av behandling, motivasjon til langvarig rehabilitering og valg av sunn livsstil. For å oppnå dette må vi se alt i lys av den enkeltes liv. Vi må også være gode rollemodeller for yngre leger, og til tross for økte krav om dokumentasjon og rapporteringer være gode klinikere med godt skjønn. Og jeg skriver mest med blyant. Som en ekte geriater!

\section{Anbefalt litteratur \\ 1. Lyon J. Alzheimer outlook far from bleak. JAMA 2017; 317: 896-8.}

Har du tips til andre personer vi kan intervjue? Ta kontakt med lisa.dahlbak.jacobsen@tidsskriftet.no 